\title{
Identification of Hepatitis E Virus in Bovine and Porcine Raw Livers
}

\author{
Hyeon-Jeong Go, Byung-Joo Park, Hee-Seop Ahn, Eu-Lim Lyoo, Dong-Hwi Kim, Joong-Bok Lee, \\ Seung-Yong Park, Chang-Seon Song, Sang-Won Lee, and In-Soo Choi*
}

Department of Infectious Diseases, College of Veterinary Medicine, Konkuk University, Seoul 05029, Republic of Korea

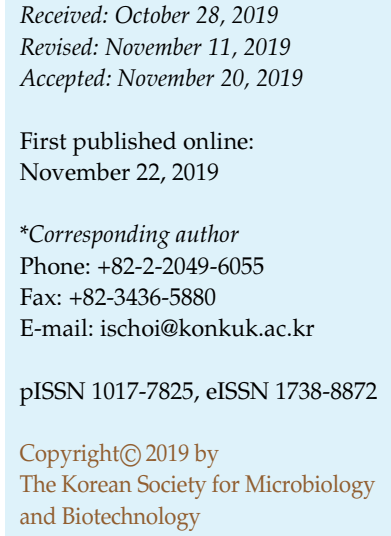

Several animal species including pigs are directly involved in the zoonotic transmission of the hepatitis E virus (HEV) to humans. This study was conducted to detect HEV in bovine and porcine raw livers by nested reverse transcription-polymerase chain reaction. Zoonotic HEV strains were identified in 1.0 and $3.0 \%$ of the tested bovine and porcine livers, respectively. HEV-4 was detected in the bovine livers, but both HEV-3 and HEV-4 were identified in the porcine livers. These results indicate that zoonotic transmission of HEV may occur via consumption of raw or undercooked livers of pigs and cattle.

Keywords: HEV-3, HEV-4, pigs, cattle, liver
Hepatitis E virus (HEV) belonging to the family Hepeviridae contains a positive-sense single-stranded RNA genome [1]. Eight genotypes in the species Orthohepevirus A have been identified in mammals. HEV generally causes acute hepatitis, and self-limiting resolutions have been observed in most cases. HEV-1 and HEV-2 infect only humans mainly in developing countries, through the consumption of contaminated drinking water [2]. Infection with HEV induces about $20 \%$ mortality in pregnant women in developing countries such as India [3, 4]. HEV-3 and HEV-4 infect both humans and several animal species, including pigs [5]. The zoonotic transmission of HEV-3 and HEV-4 frequently occurs via consumption of raw or undercooked animal meats and sausages made from porcine livers [6-8]. Recently, zoonotic infection by HEV-7 was reported in a patient who had consumed camel milk [9]. HEV-3 and HEV-4 have been identified in the fecal and liver samples of pigs in several countries such as Korea [10-14]. Particularly, HEV-3 and HEV-4 were detected in the serum samples of blood donors and patients with acute cryptogenic hepatitis in Korea [15, 16]. The HEV isolated from humans is closely related to swine HEV on the basis of genetic analysis $[15,16]$. Therefore, swine HEV may be the possible infection source in those patients. Moreover, although several studies have also indicated HEV infection in cattle $[17,18]$, detection of HEV in bovine liver samples has not yet been reported. In this study, we detected HEV-3 and HEV-4 in both porcine and bovine raw livers. To our knowledge, this is the first detection of zoonotic HEV-4 in bovine livers. Consumption of raw or undercooked porcine and bovine livers may be a plausible route of zoonotic transmission of HEV to humans.

Raw livers of cattle $(n=100)$ and pigs $(n=100)$ were purchased from local grocery markets between February 2017 and July 2018 in Seoul, Korea. Samples of about $1 \mathrm{~g}$ of each liver were ground in $3 \mathrm{ml}$ of $4 \mathrm{M}$ guanidine thiocyanate (GTC) buffer (4 M GTC, $0.25 \mathrm{M}$ sodium citrate, and 5\% trypsin-EDTA) containing $30 \mu \mathrm{l}$ of 2-mercaptoethanol as described previously [19]. The homogenates were stored at $-80^{\circ} \mathrm{C}$ until use. Total RNA was extracted from $150 \mu$ of the liver homogenates with TRIzol reagent (Sigma, Germany). A universal primer set (forward primer 5'-AAY TAT GCW CAG TAC CGG GTT G-3', reverse primer 3'-CCC TTA TCC TGC TGA GCA TTC TC-5') [20, 21] was used for amplification of a conserved region in ORF2 of HEV-3 and HEV-4. For the $1^{\text {st }}$ round of PCR, the Maxime RT-PCR PreMix Kit (Intron, Korea) was used. The PCR conditions were one cycle of RT reaction at $45^{\circ} \mathrm{C}$ for $30 \mathrm{~min}$; inactivation of RTase at $94^{\circ} \mathrm{C}$ for $5 \mathrm{~min} ; 35$ cycles of denaturation at $94^{\circ} \mathrm{C}$ for $30 \mathrm{sec}$, annealing at $51^{\circ} \mathrm{C}$ for $30 \mathrm{sec}$, 
Table 1. Detection of HEV in bovine and porcine raw liver samples.

\begin{tabular}{cccc}
\hline Animal & Number of samples & Number of HEV-positive samples (genotype) & Prevalence (\%) \\
\hline Cattle & 100 & 1 (HEV-4) & 1.0 \\
Pig & 100 & $3(1$ HEV-3, 2 HEV-4) & 3.0 \\
\hline
\end{tabular}

and extension at $72^{\circ} \mathrm{C}$ for $1 \mathrm{~min}$; and one cycle of extension at $72^{\circ} \mathrm{C}$ for $5 \mathrm{~min}$. The $2^{\text {nd }}$ round of PCR was conducted with the Maxime PCR PreMix Kit (Intron) and a primer set (forward primer 5'-GTY ATG YTY TGC ATA CAT GGC T3', reverse primer 3'-AGC CGA CGA AAT YAA TTC TGT C-5'). The PCR conditions were one cycle of initial denaturation at $94^{\circ} \mathrm{C}$ for $3 \mathrm{~min} ; 35$ cycles of denaturation at $94^{\circ} \mathrm{C}$ for $30 \mathrm{sec}$, annealing at $47^{\circ} \mathrm{C}$ for $30 \mathrm{sec}$, and extension at $72^{\circ} \mathrm{C}$ for $30 \mathrm{sec}$; and one cycle of final extension at $72^{\circ} \mathrm{C}$ for $5 \mathrm{~min}$. PCR was repeated at least twice for each sample. The HEV-specific 350-bp PCR products were identified using electrophoresis, and their DNA sequences were determined using an automatic DNA sequencer. The $304 \mathrm{bp}$ of HEV sequences without primer sequences were deposited in GenBank. The DNA sequences of HEV identified in this study were phylogenetically analyzed with representative HEV strains acquired from GenBank via the neighbor-joining method using MEGA software (ver. 6.06).

HEV was detected from one of the 100 bovine and three of the 100 porcine liver samples showing 1.0 and $3.0 \%$ prevalence, respectively (Table 1). The one HEV isolate

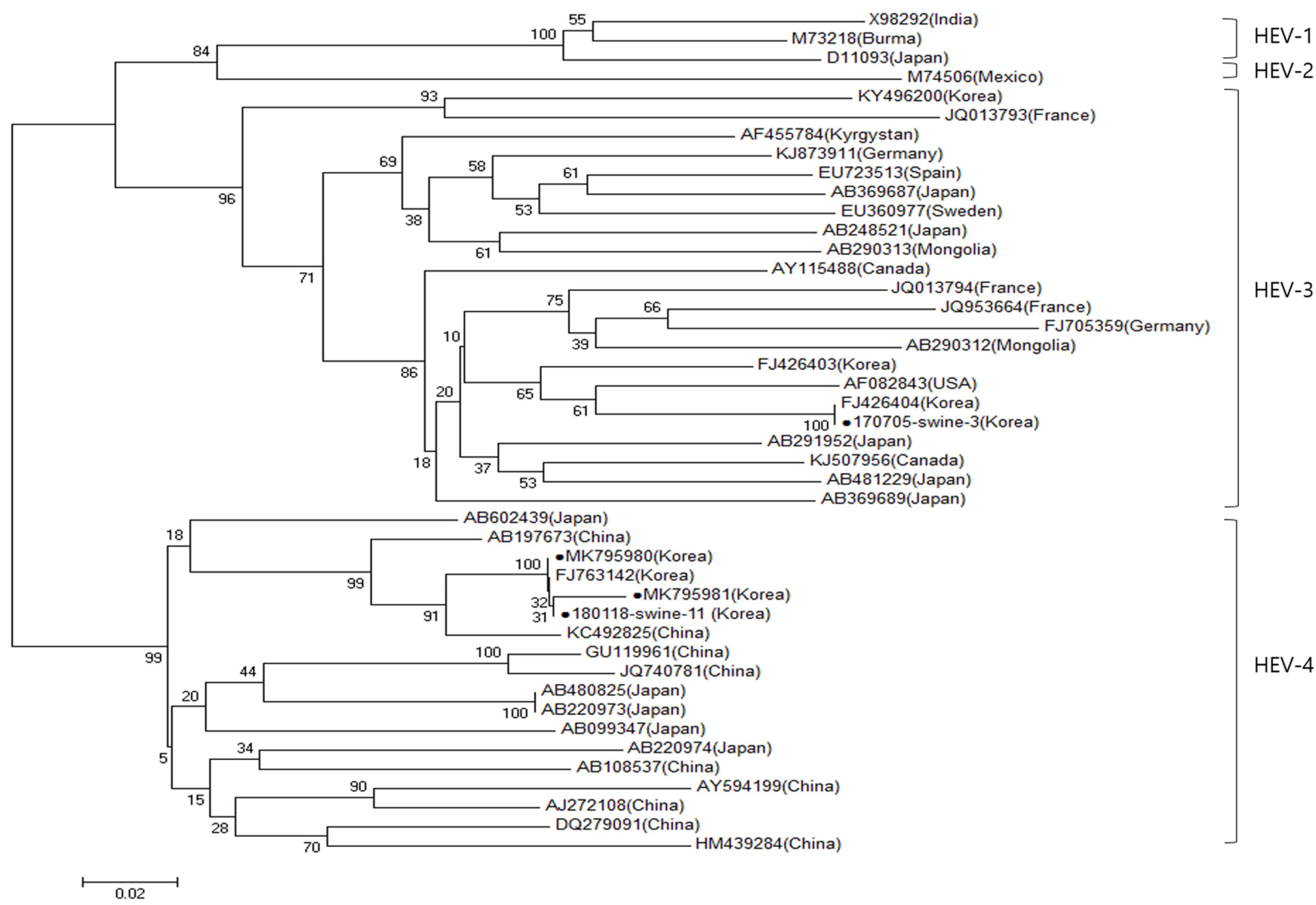

Fig. 1. Phylogenetic analysis of HEV ORF2 sequences.

Partial ORF2 sequences (304 bp) of HEV isolates obtained from bovine and porcine liver samples were compared with those of HEV-1, HEV-2, HEV-3, and HEV-4 strains identified from human and animals. Three HEV-4 (GenBank Nos. MK795980, MK795981, and ID 180118-swine-11) and one HEV-3 (ID 170705-swine-3) determined in this study are indicated as black dots. The scale bar indicates the branch length corresponding to 0.02 substitutions per site. 
identified in the bovine liver samples was HEV-4. Among the three HEV isolates detected in the porcine liver samples, one was HEV-3 and two were HEV-4. The partial genomic sequence of the one HEV-4 isolate obtained from the bovine liver sample was submitted to GenBank (accession number MK795980). The nucleotide sequence of the bovine HEV-4 showed a very close relationship with those of the human strains of HEV-4 reported from Korea (FJ763142) and China (KC492825) (Fig. 1), that is, 95.4$99.6 \%$ nucleotide identity with the two representative human HEV-4 strains (data not shown). Of the nucleotide sequences of the two HEV-4 isolates identified in the porcine liver samples, the sequence of one was deposited in GenBank (accession number MK795981). The swine HEV-4 isolate (MK795981) was also very closely related to the representative Korean and Chinese HEV-4 strains (Fig. 1). It shared 94.1-98.3\% nucleotide identity with the two human HEV-4 strains (data not shown). The nucleotide sequence of the other swine HEV-4 isolate (identification number 180118-swine-11) was $100 \%$ identical with that of the human strain of HEV-4 which was previously reported from Korea (FJ763142). The HEV-3 (identification number 170705-swine-3) obtained from the one porcine liver sample showed $100 \%$ nucleotide sequence identity with the Korean swine strain (FJ426404) previously reported by our laboratory. When the sequence of the HEV-3 was compared in the phylogenetic tree analysis, it was closely related to the swine HEV-3 strain reported from the USA (Fig. 1).

In this study, we found that small numbers of porcine and bovine livers sold in local grocery stores contained the zoonotic viruses HEV-3 and HEV-4. These results imply that raw or undercooked porcine and bovine livers may be directly involved in the zoonotic transmission of HEV to humans. Several studies have indicated that livestock products could be the source of foodborne HEV transmission to people. For example, HEV was detected in $1.9 \%, 6.4 \%$, and $11 \%$ of porcine livers in Japan, the Netherlands, and the USA, respectively [7, 22, 23]. In Japan, more than a few cases of fulminant hepatitis might have been caused by porcine liver consumption [7]. The zoonotic transmissions of HEV were further confirmed in people who consumed deer and wild boar meat $[6,8,24]$. Sausages made from porcine livers might be another source of HEV transmission to people in Europe [22, 25]. Of the eight HEV genotypes, HEV-3 has been mainly identified in the developed countries worldwide. Both HEV-3 and HEV-4 have been found in the raw porcine livers sold at grocery stores in Japan and European countries [7, 22, 23, 25]. In this study, we found both HEV-3 and HEV-4 in porcine livers sold at grocery markets in Korea. In a previous study, we detected both HEV-3 and HEV-4 in the fecal samples of growing pigs [14]. These results indicate that many pig populations reared in Korea may be infected with zoonotic HEV-3 and HEV-4. Interestingly, HEV-4 was identified from a bovine liver sample. To our knowledge, this is the first report of HEV-4 detection in bovine livers. Detection of HEV in bovine livers has been attempted in Hungary, but it was unsuccessful [26]. In contrast, HEV-4 was found in $8.79-37.14,37.14$, and $3.14 \%$ of bovine feces, milk, and sera, respectively, in China [17, 18, 27]. Collectively, these results imply that cattle are susceptible to HEV infection. Consuming raw or under cooked bovine and porcine livers should be considered a risk factor in the zoonotic transmission of HEV to people.

\section{Acknowledgments}

This study was supported by Konkuk University in 2017 (grant number: 2017-A019-0253).

\section{Conflict of Interest}

The authors have no financial conflicts of interest to declare.

\section{References}

1. Tam AW, Smith MM, Guerra ME, Huang CC, Bradley DW, Fry KE, et al. 1991. Hepatitis E virus (HEV): molecular cloning and sequencing of the full-length viral genome. Virology 185: 120-131.

2. Kang S, Myoung J. 2017. Host innate immunity against Hepatitis E virus and viral evasion mechanisms. J. Microbiol. Biotechnol. 27: 1727-1735.

3. Jilani N, Das BC, Husain SA, Baweja UK, Chattopadhya D, Gupta RK, et al. 2007. Hepatitis E virus infection and fulminant hepatic failure during pregnancy. J. Gastroen. Hepatol. 22: 676-682.

4. Myoung J, Min KS. 2019. Dose-dependent inhibition of melanoma differentiation-associated gene 5-Mediated activation of type I interferon responses by methyltransferase of Hepatitis E Virus. J. Microbiol. Biotechnol. 29: 1137-1143.

5. Kang S, Choi C, Choi I, Han KN, Roh SW, Choi J, et al. 2018. Hepatitis E virus methyltransferase inhibits type I interferon induction by targeting RIG-I. J. Microbiol. Biotechnol. 28: 1554-1562.

6. Tei S, Kitajima N, Takahashi K, Mishiro S. 2003. Zoonotic transmission of hepatitis $\mathrm{E}$ virus from deer to human beings. Lancet 362: 371-373. 
7. Yazaki Y, Mizuo H, Takahashi M, Nishizawa T, Sasaki N, Gotanda $Y$, et al. 2003. Sporadic acute or fulminant hepatitis E in Hokkaido, Japan, may be food-borne, as suggested by the presence of hepatitis E virus in pig liver as food. J. Gen. Virol. 84: 2351-2357.

8. Takahashi K, Kitajima N, Abe N, Mishiro S. 2004. Complete or near-complete nucleotide sequences of hepatitis $\mathrm{E}$ virus genome recovered from a wild boar, a deer, and four patients who ate the deer. Virology 330: 501-505.

9. Lee GH, Tan BH, Teo ECY, Lim SG, Dan YY, Wee A, et al. 2016. Chronic infection with camelid hepatitis $E$ virus in a liver transplant recipient who regularly consumes camel meat and milk. Gastroenterology 150: 355-377.

10. Jung K, Kang B, Song DS, Chae C. 2007. Prevalence and genotyping of hepatitis $\mathrm{E}$ virus in swine population in Korea between 1995 and 2004: A retrospective study. Vet. J. 173: 683-687.

11. Lee SH, Kang SC, Kim DY, Bae JH, Kim JH. 2007. Detection of swine hepatitis $\mathrm{E}$ virus in the porcine hepatic lesion in Jeju Island. J. Vet. Sci. 8: 51-55.

12. Forgach P, Nowotny N, Erdelyi K, Boncz A, Zentai J, Szucs G, et al. 2010. Detection of Hepatitis $\mathrm{E}$ virus in samples of animal origin collected in Hungary. Vet. Microbiol. 143: 106116.

13. Prpic J, Cerni S, Skoric D, Keros T, Brnic D, Cvetnic Z, et al. 2015. Distribution and molecular characterization of hepatitis E virus in domestic animals and wildlife in Croatia. Food Environ. Virol. 7: 195-205.

14. Kim YH, Park BJ, Ahn HS, Han SH, Go HJ, Kim DH, et al. 2018. Detection of hepatitis E virus genotypes 3 and 4 in pig farms in Korea. J. Vet. Sci. 19: 309-312.

15. Ahn JM, Kang SG, Lee DY, Shin SJ, Yoo HS. 2005. Identification of novel human hepatitis $\mathrm{E}$ virus (HEV) isolates and determination of the seroprevalence of HEV in Korea. J. Clin. Microbiol. 43: 3042-3048.

16. Jeong SH, Park BJ, Kim YH, Choi YS, Ahn HS, Han SH, et al. 2017. Isolation of hepatitis $\mathrm{E}$ virus genotype 4 from patients with acute cryptogenic hepatitis in Korea. J. Clin. Virol. 89: 10-13.

17. Huang F, Li YL, Yu WH, Jing SR, Wang J, Long FY, et al. 2016. Excretion of infectious hepatitis $E$ virus into milk in cows imposes high risks of zoonosis. Hepatology 64: 350-359.
18. Yan BY, Zhang L, Gong LF, Lv JJ, Feng Y, Liu JY, et al. 2016. Hepatitis E virus in yellow cattle, Shandong, Eastern China. Emerg. Infect. Dis. 22: 2211-2212.

19. Takahashi $H$, Tanaka $T$, Jirintai $S$, Nagashima $S$, Takahashi M, Nishizawa T, et al. 2012. A549 and PLC/PRF/5 cells can support the efficient propagation of swine and wild boar hepatitis E virus (HEV) strains: demonstration of HEV infectivity of porcine liver sold as food. Arch. Virol. 157: 235246.

20. Meng XJ, Purcell RH, Halbur PG, Lehman JR, Webb DM, Tsareva TS, et al. 1997. A novel virus in swine is closely related to the human hepatitis E virus. Proc. Natl. Acad. Sci. USA 94: 9860-9865.

21. Wang YC, Zhang HY, Li Z, Gu WJ, Lan HY, Hao W, et al. 2001. Detection of sporadic cases of hepatitis e virus (HEV) infection in china using immunoassays based on recombinant open reading frame 2 and 3 polypeptides from $\mathrm{HEV}$ genotype 4. J. Clin. Microbiol. 39: 4370-4379.

22. Bouwknegt M, Lodder-Verschoor F, Van Der Poel WHM, Rutjes SA, De Roda Husman AM. 2007. Hepatitis E virus RNA in commercial porcine livers in the Netherlands. $J$. Food Protect. 70: 2889-2895.

23. Feagins AR, Opriessnig T, Guenette DK, Halbur PG, Meng XJ. 2007. Detection and characterization of infectious Hepatitis E virus from commercial pig livers sold in local grocery stores in the USA. J. Gen. Virol. 88: 912-917.

24. Li TC, Chijiwa K, Sera N, Ishibashi T, Etoh Y, Shinohara Y, et al. 2005. Hepatitis $E$ virus transmission from wild boar meat. Emerg. Infect. Dis. 11: 1958-1960.

25. Wenzel JJ, Preiss J, Schemmerer M, Huber B, Plentz A, Jilg W. 2011. Detection of hepatitis E virus (HEV) from porcine livers in Southeastern Germany and high sequence homology to human HEV isolates. J. Clin. Virol. 52: 50-54.

26. Reuter G, Fodor D, Forgach P, Katai A, Szucs G. 2009. Characterization and zoonotic potential of endemic hepatitis E virus (HEV) strains in humans and animals in Hungary. J. Clin. Virol. 44: 277-281.

27. Hu GD, Ma X. 2010. Detection and sequences analysis of bovine hepatitis $\mathrm{E}$ virus RNA in Xinjiang autonomous region. Bing Du Xue Bao 26: 27-32. 